\title{
Comparative Analysis of Stock Price before and after Announcement of Annual Report Awards (Study of Banking Sector Companies Listing on the Indonesia Stock Exchange)
}

\author{
Muspa \\ \{muspa69@yahoo.co.id\}
}

Nitro Business and Finance Institute, Makassar, Indonesia

\begin{abstract}
This study aims to determine and analyze differences in stock prices before and after the announcement of the Annual Report Awards in the banking sector on the Indonesia Stock Exchange. The analytical method used in this research is quantitative descriptive analysis method. The analysis used was the Paired Sample T-Test with IBM SPSS Version 20.0. The results showed that there was no significant difference between the stock price before and after the announcement of the Annual Report Awards in the king sector on the Indonesia Stock Exchange, as indicated by the significance value of the Paired Sample T-Test of $0.205 * 0.05$. In addition, the test results show that there is a weak and insignificant relationship between stock prices before and after the announcement of the Annual Report Awards, as indicated by the correlation coefficient of 0.090, significant 0.637 .
\end{abstract}

Keywords: stock price; annual report awards

\section{Introduction}

The capital market is a financial instrument that trades securities in the form of bonds and equity or shares for the long term issued by the government or private companies, and their activities are carried out in the bourse where brokers meet investors. The capital market is said to have an economic function because the capital market provides facilities or vehicles to bring together two interests, namely those who have excess funds (investors) and those who need funds (issuer) [1]. With the capital market, public companies can obtain fresh funds from the public through the sale of shares by the procedure of Initial Public Offering (IPO) or initial public offering (listing its shares for the first time stocked) or through debt securities (bonds).

One of the instruments traded on the market is shares. According to Tjiptono and Fakhrudin [2], shares can be defined as a sign of ownership of a person or entity in a company or limited liability company. Shares are known for their characteristics of high risk - high return prices, which means that shares can not only provide a high level of profit in a short period of time but can also provide a high level of loss along with fluctuating stock prices.

The stock price is the price formed from the interaction of the seller and buyer of 
the stock, which is motivated by the expectation to benefit from the company. According to [3], factors that affect the stock price include earnings per share (EPS). The interest rate, the amount of cash dividends given, the amount of profits earned by the company, the level of risk and returns, but not only economic factors that influence the market price but also non-economic as well as awards to companies that are considered to have provided the most information open in terms of its annual financial statements compared to other companies, one of which is the Annual Report Awards.

Annual Report Awards (ARA) is the highest award for the quality of annual reports that are published regularly by the company. This activity was held in collaboration with BAPEPAM-LK, the Ministry of SOEs, the Indonesian Accountants Association (IAI), Bank Indonesia, PT. IDX, DG Tax and National Governance Policy Committee (KNKG). The ARA award is given to companies that have fulfilled the completeness criteria in presenting financial statements. The annual report is no longer limited to reporting accountability at the General Meeting of Shareholders but has become the role of effective communication media for all parties regarding the company's performance and prospects going forward. Participation in the Annual Report Awards (ARA) is a manifestation of the implementation of Good Corporate Governance and can further strengthen the company's presence in the eyes of investors [4].

One form of appreciation at the Annual Report Awards (ARA) is the award in the category of banking financial statements. Submitting a quality financial report by the bank is important; this is because banks manage funds originating from the public (third-party funds), in addition to the financial statements of the bank that are needed by investors in making the right investment decisions. The following is the average data of share prices of banking companies included in the 2018 Annual Report Awards (ARA) winners.

Table 1. Average Stock Price of Winning Banking Companies Annual Report Awards (ARA) 2018

\begin{tabular}{llc}
\hline No & \multicolumn{1}{c}{ Companies } & Stock Price (Rp) \\
\hline 1 & PT Bank Tabungan Negara (Persero) Tbk. & 1.840 \\
2 & PT Bank Negara Indonesia (Persero) Tbk. & 5.483 \\
3 & PT Bank Sinarmas Tbk. & 860 \\
4 & PT BPD Jawa Timur Tbk. & 605 \\
5 & PT BPD Jawa Barat dan Banten Tbk. & 590 \\
6 & PT Bank Rakyat Indonesia (Persero) Tbk. & 11.725 \\
\hline
\end{tabular}

Based on table 1 shows that the average share price in banking sector companies before the announcement of the Annual Report Awards has fluctuated, which means that the stock price depends on the strength of demand and supply for a stock. Therefore, with the Annual Report Awards (ARA) it is expected that this Award will be information that will be responded to by investors and is expected to influence the movement of banking sector stock prices on the Indonesia Stock Exchange.

Research on the effect of non-economic announcements on stock prices still yields conflicting results. Research conducted by Ulum (2010) on the effect of the 2008 Annual Report Awards (ARA) awarding on stock price move and trading volume of manufacturing sector companies shows that there is no difference in average stock prices before and after the awarding of the Annual Report Awards (ARA) 2008. Another result was found by Ekawati [1] who examined the analysis of differences in share prices before and after the announcement of the 2007 Annual Report Awards (ARA) on the Jakarta ck Exchange, which showed that there were differences in stock prices before and 
after the announcement of the 2007 Annual Report Awards (ARA) on the Jakarta Stock Exchange.

The differences in the results of these studies indicate that research on noneconomic effects on stock prices is an interesting thing to study. Therefore, based on the background that has been studied previously researchers are interested in re-examining the effect of the announcement of the Annual Report Awards (ARA) with the formulation of the problem in this study is "Is there a difference in stock prices before and after the announcement of the Annual Report Awards in the banking sector registered in Indonesia stock exchange?".

\section{Literature Review}

The stock price is the price formed on the stock exchange. Generally, the stock price is obtained to calculate the value of the stock. The further the difference is, then this reflects too little information flowing into the stock exchange. To find out how far change in a company's stock price, it can be seen by using the stock price index indicator. The stock price index is an indicator that shows the movement of stock prices that serves as an indicator of market trends, meaning that the index movement describes the condition of the market at one time, whether the market is active or lethargic.

The stock price is the buying and selling price that is currently in effect in the securities market, which is determined by market power in the sense that it depends on the strength of demand (supply) and supply (selling demand). The stock market price also shows the value of the company itself. The higher the value of a company's stock market price, the investor will be interested in selling its shares. The stock market is one indicator of a country's economy, so we need a calculation of the transactions that occur in the exchange during a certain period. This calculation will be used as a benchmark for a country's economic conditions. For countries in Indonesia, the calculation is the calculation of the Composite Stock Price Index (CSPI).

The stock price is the market price, that is, the price formed in the stock trading market [3] Too little information flowing into the stock market causes the stock price to be determined by psychological pressure from sellers and buyers (irrational actions). The company has increased, then investor confidence will also increase so that the stock price usually increases.

Factors that can affect stock prices according to Weston and Brigham in Chadijah [5] are projected earnings, earnings per share (net income per share), interest rates, risk and returns, dividend distribution policies, and corporate actions that conducted by the issuer. According to Ang (1997) in Anindhita [6], the value of a stock based on its function can be divided into three types, namely:

1. Per Value (Nominal Value) is the value listed on the relevant stock that functions for accounting records and is not used to measure anything.

2. Base Price is the price used in the calculation of stock index prices that will change according to the actions of the issuer.

3. Market Price is the price of a stock in the ongoing market. If the stock exchange market is closed, then the market price is the closing price. Thus this market price will state the ups and downs of shares. 


\subsection{Efficient Market Theory}

Jogianto [3] states that market efficiency is the relationship between the prices of securities and information. The term efficient capital market can be interpreted differently for different purposes. An efficient market is a market where the price of a security traded reflects all available information.

Tandelilin [7] states that the information available can include all available information both past information (for example, company profits last year), as well as current information (for example plans to increase dividends this year), as well as information that is as an opinion/opinion rational circulating in the market that can affect price changes (for example if many investors in the market think that stock prices will rise, then this information will later be reflected in changes in stock prices that tend to rise). Jogiyanto [3] explains the form of an efficient market including.

a. Weak Form: assumes that all stock prices reflect all available market information (historical), so that past price and trading volume information have no relationship with the direction of future price movements. The conclusion is that investors cannot rely on technical analysis to produce above-normal profits.

b. Semi-strong form: assumes that all share prices reflect all non-market public information. Prices will immediately "adjust" to all public information that has just been informed. For example: research on new shares, earnings announcements, and dividends, company profit estimates, changes in accounting practices, mergers, stock split, or other corporate actions. The conclusion is that investors cannot use fundamental analysis to produce profits above normal.

c. Strong Form: assumes that all stock prices reflect all market information, public, and sources from within the company (private/private/inside) publicly available. This information includes information that can be stained from the results of fundamental analysis. The conclusion is: there is no group that monopolizes access to information related to stock prices so that it earns above-normal profits by using inside information. The capital market will be perfect where all information is free and cost available to anyone at the same time.

The implication of an efficient market theory (Efficient Market Hypothesis Theory) on financial management is that the company will make every effort to improve the company's financial performance better from year to year, for example by doing corporate actions such as issuing new shares, announcing increases in profits and dividends, mergers stock split, or other corporate actions. With the existence of efficient market theory, analysts or company leaders try hard to maximize work to provide the best performance for the company.

\subsection{Signaling Theory}

Budiarto and Baridwan [8] state that the main assumption in signal theory is that management has accurate information about the value of the company that is unknown to outside investors and management is someone who is always Qing to maximize the expected incentives, meaning that management generally has more information complete and accurate compared to external parties (investors) regarding the factors that affect the value of the company.

According to the signal theory, there is information asymmetry managers and investors. Managers know the prospects of the company in the future, while investors do 
not know. Asymmetry information is private information that is only held by informed investors. Information asymmetry will occur if management does not fully obtain the information that can affect the stock market, then the market will respond to that information as a signal reflected by changes in stock prices and stock returns.

\subsection{Event Study}

Kothari and Warner in Halim [9] state that, basically, the event study focuses on the effect or effect of an "announcement" in the short term to provide a relevant understanding of company decisions/policies. According to them, the event study reflected the impact of the announcement of a company policy or decision.

In financial management literature, company policies can be divided into 3 (three) important decisions, namely investment decisions, financing decisions, and dividend decisions. Aside from being based on an announcement or policy, the event study also discusses/studies the existence of an event, an event that can give effect or reaction to stock trading in the short term. This event can be in the form of political, social, natural disasters, or in the form of a religious day commemoration. All of these events will certainly give an effect or consideration to investors to make a short-term investment decision, especially the investors who want capital gains.

\subsection{Annual Report Awards (ARA)}

Annual Report Awards are annual awards given to companies as a form of transparency of information on efforts to implement good company management and integrity. The award event was held in collaboration with seven organizing agencies, namely the Financial Services Authority, the Ministry of SOEs, the Directorate General of Taxation, the National Committee on Governance Policy (KNKG), Bank Indonesia, the Indonesia Stock Exchange, the Indonesian Accounting Association (IAI).

\subsection{Relationship between Annual Report Awards and Stock Price}

Annual Report Awards (ARA) are awards given to companies that meet the completeness criteria in the presentation of annual financial statements, especially for information on the company profile, disclosure of the company's vision and mission relating to the implementation of Good Corporate Governance, analysis and management discussion on company performance, reports finance in accordance with accounting principles and applicable capital market regulations, and other information relevant to the needs of stakeholders (Bapepam 2002, in Ekawati, [1]). This award is expected to make a positive contribution to efforts to restore investor confidence and national economic recovery in general.

The award is a signal for investors in conducting transactions on the Indonesia Stock Exchange. If the award has information content, then the market will respond as reflected through share price movements. This happens because by winning the Annual Report Award, the company's image will be better in the eyes of investors and further enhance investor confidence in the company [1].

\subsection{Prior Research}


The previous studies supporting this research include:

a. Research conducted by Ekawati [1] who examined the analysis of differences in stock prices before and after the announcement of the Annual Report Awards (ARA) 2007 on the Indonesia Stock Exchange. Based on research results, it is known that there are differences in share prices before and after the announcement of the Annual Report Awards (ARA) 2007 on the Indonesia Stock Exchange.

b. Research conducted by Darmawan [10] on the Effects of the Individual Report Awards (ARA) (Event Study in ARA Recipient Companies 2009-2012). The value of the company in this study is measured through these prices, abnormal returns, and stock trading volume. The results showed that there were differences in average stock prices before and after the Announcement of Annual Report Awards (ARA) on the Indonesia Stock Exchange.

\subsection{Hypothesis}

Based on the theoretical foundation and previous research that has been stated above, the hypothesis in this study is that there is a significant difference in stock Yes before and after the announcement of the Annual Report Awards to the banking sector on the Indonesian Stock Exchange.

\section{Research Method}

\subsection{Population and Sample}

The population in this study is the banking sector companies listed on the Indonesia Stock Exchange, amounting to 43 banking sector companies. The sample in this study uses a purposive sampling method, namely the determination of the sample by determining certain criteria in accordance with the objectives of the study. The criteria in this study are:

a. Banking companies that received the 2018 Annual Report Awards.

b. The banking company is actively traded in shares during the research period.

Based on the specified sample selection criteria, 6 banking sector companies were obtained as the research samples.

\subsection{Operational Definitions}

1. Annual Report Awards

Annual Report Awards are awards given to companies that meet the completeness criteriainthepresentation of annual financial statements. Annual Report Awards 2018

2. Stock Price

The stock price used in this study is the daily closing price of shares of banking sector companies listed on the Indonesia Stock Exchange as the research sample. The observation period taken is the stock price 30 working days before and 30 working days after the announcement of the Annual Report Awards.

\subsection{Analysis Method}

The analytical method used in this study is a quantitative descriptive method, which is 
a research method using a numerical approach. In this case, the stock price data of the banking sector before and after the announcement of the 2018 Annual Report Awards were then analyzed using statistical calculations.

1. Normality Test

Data normality test in research is used before hypothesis testing to determine whether the data is normally distributed or not, which will determine the use of statistical test equipment. Test for normality in this study using Kolmogorov Smirnov.

According to Ghozali [11], Kolmogorov Smirnov's decision- making criteria are:

a. Significance value or probability value $<0.05$, the distribution is not normal.

b. Significance value or probability value $>0.05$, the distribution is normal.

2. Paired Sample T-test

Based on the problem to be discussed and the hypothesis to be tested, the analytical tool used is the Paired Sample T-Test technique, with the window period is the stock price 30 days before and after the announcement of the Annual Report Awards on listed banking sector companies on the Indonesia Stock Exchange.

According to Gujarati [12], different test paired sample t-test is done by comparing the difference between the two average values with the standard error of the average difference of the two samples. To measure and analyze this research, the SIBS SPSS Version 20.0 was used. Paired Sample T-Test is used to determine whether there are differences in stock prices of banking sector companies before and after the announcement of the Annual Report Awards. According to Gujarati [12] Paired Sample T-Test.

\section{Research Result and Discussion}

\subsection{Research Result}

This study aims to analyze and determine differences in stock prick before and after the announcement of the Annual Report Awards in the banking sector on the Indonesia Stock Exchange.

Descriptive statistics in this study were used to provide information about the research variables used in the form of stock prices in the banking sector. Descriptive statistics for stock prices can be seen as follows:

Table 2. Descriptive Statues Stock Price Banking Sector

\begin{tabular}{lccccc}
\hline & N & Minimum & Maximum & Mean & Std. Deviation \\
\hline Before After & 00 & Z675.B3 & Z8OE.8Z & 3749.6945 & 34.61032 \\
& 30 & 3663.33 & 3909.17 & 3763.6388 & 50.79608 \\
& & & & & \\
Valid N (listwise) & & & & &
\end{tabular}

Source: Data is processed Using IBM SPSS Version 20.0

Based on table 2 it can be seen descriptive statistics of the banking sector stock 
prices before and after the announcement of the Annual Report Awards (ARA) which can be explained as follows:

a. Share Prices Before Annual Report Awards (ARA)

The lowest banking stock price before the announcement of the Annual Report Awards (ARA) of Rp3,675.83, the highest price of Rp3,805.83. and an average share price of Rp3,749.6945 with a standard deviation value of Rp34.61032

b. Share Price After Annual Report Awards (ARA)

The lowest share price of the banking sector after the announcement of the Annual Report Awards (ARA) of Rp3,663.33, the highest share price of Rp3,909.17, and an average share price of Rp3,763.6388 with a standard deviation value of 50.79608 .

\subsection{Analysis Result}

This study used a paired sample t-test analysis tool with IBM SPSS Version 20.0.

a. Data Normality Test

The data normality test in this study uses the Kolmogorov Smirnov Test. The basis for making the Kolmogorov Smirnov Test is that the null hypothesis (H0) is accepted, and the alternative hypothesis $(\mathrm{H} 1)$ is rejected if the probability is $<0.05$. then the data distribution does not follow the normal distribution. Instead, the null hypothesis (H0) is rejected, and the alternative hypothesis (H1) is accepted if the probability is $>0.05$. which means that the data distribution follows the normal distribution. The results of the Kolmogorov Smirnov Test on the banking sector stock prices before and after the announcement of the Annual Report Awards (ARA) can be seen as follows:

Table 3. Stock Price Data Normality Test One-Sample Kolmogorov-Smirnov Test

\begin{tabular}{lrr}
\hline \multicolumn{2}{c}{ before ARA } & After ARA \\
\hline $\mathrm{N}$ & \multicolumn{2}{c}{ Pr } \\
Mean & & \\
Normal Parameters* & 3749.6945 & 3763.6388 \\
Std. Deviation & 34.61032 & 50.79608 \\
$\quad$ Absolute Most & .079 & .145 \\
$\quad$ Extreme & .052 & .141 \\
$\quad$ Differences & -.079 & -.145 \\
$\quad$ Positive & .435 & .792 \\
Negative & .991 & .557 \\
Kolmogorov-Smirnov Z & Asymp. Sig. (2-tailed) &
\end{tabular}

Source: Data is processed Using IBM SPSS Version 20.0

Based on table 3 the normality test results can be explained using the Kolmorov Smirnov Test as follows:

1) The probability value of the stock price of the banking sector before the announcement of the Annual Report Awards (ARA) of $0.991 \mathrm{z} \mathrm{0.05}$. This means that the stock price data of the banking sector prior to the announcement of the Annual Report Awards (ARA) is normally distributed.

2) The probability value of the stock price of the banking sector after the announcement 
of the Annual Report Awards (ARA) of $0.557 * 0.05$. This means that the banking sector stock price data after the announcement of the Annual Report Awards (ARA) are normally distributed.

\section{b. Research Hypothesis Testing}

Based on the results of the normality test on the stock prices of the banking sector before and after the announcement of the Annual Report Awards (ARA), it can be concluded that the stock price data is normally distributed that it can then be tested for research hypothec using the Paired Sample T-test (paired sample test). Paired Sample T-test is used to analyze whether there is a significant difference between the stock prices of the banking sector before and after the announcement of the Annual Report regards (ARA).

The hypothesis in this study states that there are allegedly significant differences in stock prices before the announcement of the Annual Report Awards (ARA) in the banking sector on the Indonesia Stock Exchange. The final results of the hypothesis test for the see price of the banking sector on the Indonesia Stock Exchange before and after the announcement of the Annual Report Awards (ARA) can be seen as follows:

1. Paired Sample Statistics

Paired Sample Statistics is used to see the increase/decrease in average stock prices of the banking sector before and after the announcement of the Annual Report Awards (ARA). Paid sample statistics test results of the banking sector's stock prices before and after the announcement of the Annual Report Awards (ARA) can be seen as follows.

Table 4. Paired Sample Statistics

\begin{tabular}{lccll}
\hline & Mean & $\mathrm{N}$ & std. Deviation & Std. Error Mean \\
\hline BEFORE & 3749.6945 & 30 & 34.61032 & 6.31895 \\
AFTER & 3763.6388 & 30 & 50.79608 & 9.27405 \\
\hline
\end{tabular}

Source: Data is Processed using IBM SPSS Version 20.0

From the results of paired samples statistics seen in table 4, it can be seen that the average stock price of the banking sector before the announcement of the Annual Report Awards (ARA) was Rp3.749.6945 while after the announcement of the Annual Report Awards (ARA) of Rp3763.6388, which means an increase in the price of shares in the banking sector by Rp13.94433.

2. Paired Sample Correlations

Sugiyono (2012:184) states that Paired Sample Correlations are values that indicate the strength and direction of the linear relationship be Meen Mo random variables. The results of paired sample correlations of banking sector stock prices before and after the announcement of the Annual Report Awards (ARA) can be seen as follows:

Table 5. Paired Sample Correlations

\begin{tabular}{cccc}
\hline & N & Correlation & Sig. \\
\hline BEFORE \& AFTER & 30 & 090 & .637 \\
\hline
\end{tabular}

Source: Data is processed using IBM SPSS Versi 20.0 
Based on table 5, it can be seen that the correlation coefficient is 0.090 , with a significance level of 0.637 . This means that there is a weak and insignificant relationship between the stock prices of the banking sector before and after the announcement of the Annual Report Awards (ARA).

\section{Paired Sample T-Test}

The paired sample T-test results of the banking sector stock prices before and after the announcement of the Annual Report Awards (ARA) can be seen as follows:

Table 6. Paired Sample T-Test

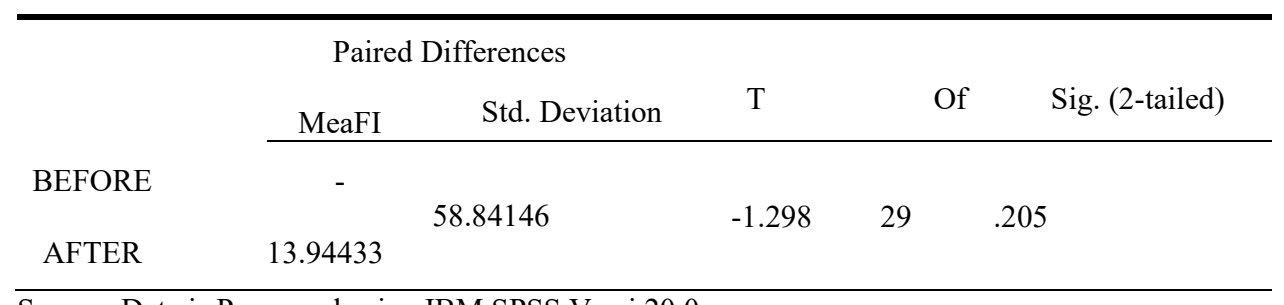

Source: Data is Processed using IBM SPSS Versi 20.0

Table 6 shows that the significance test $r$ is from the Paired Sample T-Test for the stock prices of the banking sector in the Indonesian stock exchange before and after the announcement of the Annual Report Awards (ARA) show a significance value * alpha 0.05 . which is equal to $0.205 * 0.05$, then the hypothesis is nil (H0) is accepted, and the alternative hypothesis $(\mathrm{H} 1)$ is rejected.

Thus the results of the hypothesis test showed that the hypothesis stating that there were allegedly significant differences in share prices before and after the announcement of the Annual Report Awards (ARA) in the banking sector on the Indonesia Stock Exchange was denied.

\section{Discussion}

This study aims to analyze and determine differences in stock prick before and after the announcement of the Annual Report Awards in the banking sector on the Indonesia Stock Exchange. The research period used in this study is 30 days before and after the announcement of the Annual Report Awards to the banking, sir, on the Indonesia Stock Exchange. This study uses a sample of 6 banking sector companies on the Indonesia Stock Exchange and falls into the Annual Report Awards (ARA) category.

The paired samples statistics test results show that the average stock price of the banking sector on the Indonesia Stock Exchange before the announcement of the Annual Report Awards (ARA) was Rp3.749.6945 while after the announcement of the Annual Report Awards (ARA) of Rp3763.6388, which meant an increase the banking sector stock price of Rp13.94433.

Based on the results of the paired sample correlation analysis, a correlation coefficient of 0.090 was obtained with a significance level of 0.637 , which means that there was a weak and insignificant relationship between the stock prices of the banking sector list on the Indonesia Stock Exchange before and after the announcement of the Annual Report Awards (ARA). 
The result of the significance test of the stock price using Paired Sample T-Test shows a significance value of $0.205 \mathrm{z} 0.005(5 \%)$ which means that there is no significant difference in the stock prices of banking sector companies on the Indonesia Stock Exchange before and after the announcement of the Annual Report Awards (ARA). Although there was an average increase in the share price of Rp13.94433, the increase was not significant and based on statistical calculations using the Paired Sample T-Test. The increase in share price after the announcement of the Annual Report Awards (ARA) was considered to be no different from the stock price before the Annual announcement Report Awards (ARA).

The results of this study indicate that the announcement of the Annual Report Awards (ARA) has no information content for investors, so investors do not respond to the announcement of the Annual Report Awards (ARA). It can be concluded that the 2018 Annual Report Awards (ARA) publication information is not effective information in the capital market, thus being able to influence investors' decisions to invest in banking sector shares included in the Annual Report Awards (ARA). This is thought to have happened due to the following factors:

1. Banking companies that won the 2018 Annual Report Awards (ARA) are large banking companies, well known to the public, and stable in performance. so investors assume that the company is already good in terms of corporate governance. Therefore, although it received an award, it did not change the desire of investors to invest in banking companies that won the 2018 Annual Report Awards (ARA). Nittayagasetwat in Kemala and Ulupui [13] argues that information on the publication of the Annual Report Awards (ARA) from year to year only shows that the concern of companies in Indonesia for the openness and completeness of the presentation of financial statements and the implementation of good corporate governance is starting to grow. Therefore the publication of the Annual Report Awards (ARA) is more beneficial to companies participating in this award compared to investors, where companies can find out how well the presentation of financial statements and the implementation of corporate governance conducted by the company based on the evaluation of the jury of the Annual Report Awards (ARA).

2. Investors are taking a wait and see attitude towards the situation in the capital market around the day of the announcement of the Annual Report Awards (ARA). This is because inflation data for the period August 2018 to October 2018 shows an increase in inflation of $0.52 \%$ i.e., amounted to $2.79 \%$ in August $2018,3.07 \%$ in September, and 3.31\% in October 2018 (bi.go.id). Therefore investors are cautious in conducting stock transactions due to the inflation increase.

The results of this study contradict the research conducted by Ekawati [1], which stated that there were differences in stock prices before and after the announcement of the Annual Report Awards (ARA).

\section{Conclusions and Suggestion}

\subsection{Conclusions}

The aim of this research is to analyze and find out the differences in stock rises before and after the announcement of the Annual Report Awards in the banking sector on the Indonesia Stock Exchange. Based on the risks of research and discussion, it can be 
concluded that there are no significant differences in the prices of shares of banking sector companies in the Indonesia Stock Exchange before and after the announcement of the Annual Report Awards (ARA).

\subsection{Suggestions}

1. For Investors

It is expected that investors consider the publication of the Annual Report Awards as a way to make investment decisions by collecting shares that are included in the category of Annual Report Awards (ARA). This is important for investors because by investing their shares in companies that are transparent in presenting reports financial and good corporate governance will make investors feel safer in investing in these companies and can minimize the risk of an investment that will arise.

2. For Further Researchers

It is expected that further researchers will increase the number of research samples by examining all companies listed on the Indonesia Stock Exchange and included in the category of Annual Report Awards (ARA). In addition, it is expected that future researchers will examine other variables such as stock returns and use shorter research periods in order to find out investor attitudes regarding the announcement of Annual Report Awards (ARA) in the short term.

\section{References}

[1] Ekawati, R. K.: "Analisis perbedaan harga saham sebelum dan sesudah pengumuman Annual Report Awards (ARA) di Bursa Efek Jakarta," in Forum Bisnis Dan Kewirausahaan Jurnal Ilmiah STIE MDP, vol. 1, no. 1, pp. 33-41 (2011)

[2] Darmadji, T., and Fakhruddin, H. M.: "Pasar modal di indonesia," Jakarta: Salemba Empat, (2001)

[3] Hartono, J.: “Teori dan praktik portofolio dengan excel," Jakarta: Salemba Empat (2014)

[4] Armin, M. I.: "Pengaruh Indonesia Sustainability Reporting Awards (1sra) pada Pengembalian Abnormal dan Volume Perdagangan Saham (Studi Empiris Perusahaan-Perusahaan Pemenang Penghargaan ISRA 2009-2010),” vol. 13, no. 128, p. 234 (2011)

[5] Chadijah, S.: "Analisis pengaruh harga, volume perdagangan, return, frekuensi perdagangan, dan volatilitas harga saham terhadap Bid Ask Spread perusahaan yang melakukan stock split periode 2004-2008," (2010)

[6] Anindhita, G., and Mahfud, K.: "Analisis Reaksi Pasar Atas Pengumuman Dividen Sebelum Dan Sesudah Ex-Dividend Date (Studi Kasus pada Kelompok Cash Dividend Final Naik dan Turun pada Perusahaan-perusahaan yang Terdaftar di BEJ Tahun 2004-2006)." Universitas Diponegoro (2010)

[7] Eduardus, T.: "Analisis Investasi dan Manajemen Portofolio," Yogyakarta PT. BPFE (2001)

[8] Budiarto, M. A., and Baridwan, Z.: "Pengaruh pengumuman right issue terhadap tingkat keuntungan dan likuiditas saham di Bursa Efek Jakarta periode 1994-1996." Universitas Gadjah Mada (1998)

[9] Halim, A.: “Analisis investasi.” Jakarta: Salemba Empat (2005)

[10] Darmawan, A. B.: "Pengaruh annual report award (ara) terhadap nilai perusahaan (Event Study pada Perusahaan Peraih ARA 2009-2012)," (2015)

[11] Ghozali, I.: "Aplikasi Analisis Multivariat dengan Program IBM SPSS 20 (Edisi keenam). Semarang: Universitas Diponegoro. Sugiyono.(2008)," Metod. Penelit. Bisnis, pp. 1375-2085, (2012)

[12] Gujarati, N.: "Damodar. Basic Econometrics." McGraw-Hill Companies. (2004)

[13] Kemala, K. C., and Ulupui, I. G. K. A.: "Reaksi Pasar terhadap Publikasi Annual Report 
Award," E-Jurnal Akunt., pp. 171-185 (2015) 